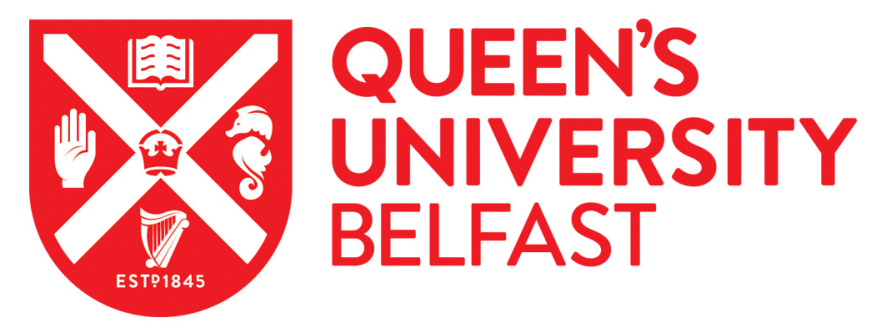

\title{
Discovering Film on Irish Television: fragments from the RTÉ Archives 1960-1965
}

Barber, S. (2018). Discovering Film on Irish Television: fragments from the RTÉ Archives 1960-1965. Historical Research, 91(254), 791-809. https://doi.org/10.1111/1468-2281.12242

\author{
Published in: \\ Historical Research
}

\section{Document Version:}

Peer reviewed version

Queen's University Belfast - Research Portal:

Link to publication record in Queen's University Belfast Research Portal

Publisher rights

(C) 2018 Institute of Historical Research.

This work is made available online in accordance with the publisher's policies. Please refer to any applicable terms of use of the publisher.

\section{General rights}

Copyright for the publications made accessible via the Queen's University Belfast Research Portal is retained by the author(s) and / or other copyright owners and it is a condition of accessing these publications that users recognise and abide by the legal requirements associated with these rights.

Take down policy

The Research Portal is Queen's institutional repository that provides access to Queen's research output. Every effort has been made to ensure that content in the Research Portal does not infringe any person's rights, or applicable UK laws. If you discover content in the Research Portal that you believe breaches copyright or violates any law, please contact openaccess@qub.ac.uk. 
'Discovering Film on Irish Television: fragments from RTÉ Archives 1960-1965’

\begin{abstract}
This work explores film and television in Ireland in the early 1960s. Focusing on national broadcaster RTÉ, it uses archival programme footage and broadcast listings to examine television's relationship with film and cinema. This material, which includes excerpts from arts and culture programmes and interviews with actors, suggests an intersection between film, cinema and television in 1960s Ireland.
\end{abstract}

\title{
Keywords: RTÉ, film, 1960s, television, archives
}

\section{Introduction}

This article explores the intersection of film and television through a study of film and cinema material on Irish national broadcaster Telefís Éireann (hereafter referred to as RTÉ) in its earliest years of broadcast. Focusing on the period 1960-1965 it examines the interconnectedness, or otherwise, of film and television in Ireland in the early 1960s, and sheds light on the debates about film and discourses about cinema being relayed to viewers through the new television medium. In doing so, this research draws upon a number of key sources, specifically the RTÉ broadcast listings guide (published in this period as RTV Guide) and accessed from the National Library in Dublin and RTÉ Archives at Donnybrook. This research also draws upon archival footage accessed via RTÉ's internal database and this material - written and visual - will be used to map the cultural place of film on the Irish broadcaster in the early 1960s. Funded by a scoping grant from the Federation of International Television Archives (FIAT/IFTA) and supported and enabled by RTÉ Archives, this work counters examinations of film and television as separate cultural entities. It builds on the approach outlined by Su Holmes, to draw explorations of film and television together. ${ }^{1}$ In her work on 1950s Britain, Holmes proposes that exploring 'television's world of cinema' - specifically the way in which cinema and film are discussed on television - offers an alternative lens through which to explore the interaction of the two media. This research develops Holmes' approach by foregrounding underexplored broadcaster archival material to indicate how material created for television broadcast can be used to enhance understandings of and debates around film culture.

Most scholars of film or television pay due attention to the other medium, yet few explore the relationship between the two. Within scholarship about Britain, studies of 
particular decades of film culture have devoted a great deal of attention to television, yet frequently this focuses on aspects of cultural exchange, on particular programmes, or on the industrial structures which separate the two media. Recently work on the BBC, ITV and Channel 4 has identified ways in which television is contributes to or directly informs film culture. Mary Irwin's work on the BBC arts and culture programme 'Monitor' which ran from 1958-1965 explores how this television programme contributed to broader artistic culture, as does John Walker's examination of 'arts television', while John Hill and Lez Cooke's work on regional British television drama has unearthed programme material which has been overlooked and underexplored. ${ }^{2}$ Finally, work on Channel 4 has explored the broadcaster's role in funding feature films from the 1980 s onwards. ${ }^{3}$ All of this work is important for rethinking the way in which film and television are connected.

For Ireland, there are a range of detailed explorations of the early years of RTÉ and work by John Bowman, Robert Savage, Christopher Morash, Martin McLoone and John MacMahon sheds light on the material shown on the broadcaster and how this relates to RTÉ's underlying ideology. ${ }^{4}$ Work on film in Ireland is also detailed with significant interventions from Ruth Barton and Lance Pettitt, yet work on RTÉ and its particular relationship to film is sparse. ${ }^{5}$ Additionally, explorations of RTÉ's programming, often exclude film output altogether. For example, Roddy Flynn's detailed examination of RTÉ content throughout the 1960s offers powerful evidence of the broadcaster's reliance on cheap, imported US content to fill the schedule, yet there is no mention of how film material contributed to scheduled broadcasts. ${ }^{6}$ This work directly addresses this omission and explores both the significance of film as scheduled broadcast output and its importance as a point of discussion within arts and culture programming.

McLoone has argued that prevailing hierarchies of culture have ensured that television within Ireland was and continues to be consistently perceived as 'an ephemeral and disposable medium' ${ }^{7}$ Yet the failure to consider television as a cultural form worthy of study is certainly not specific to Ireland, and is often the fate of small nation broadcasters. RTÉ's close guard upon its own archives, and reluctance to collaborate with scholars and historians has ensured that scholarly attention has been focused upon its broadcast output, as well as the political and cultural 
implications of its policies which can be traced through press, and government legislation. In recent years RTÉ has begun to effectively explore its own output, focusing on making material from its archives widely available online and drawing attention to the material that exists as part of its extensive collections. This research was undertaken with the full co-operation of RTÉ Archives and would not have been possible without the assistance and expertise of the archives staff in helping track down elusive fragments of content as well as explaining the mysteries of the internal catalogue.

Searches in the RTÉ archive revealed some surviving material from the early 1960s including recorded interviews with actors and directors, and coverage of film festivals. Through a detailed exploration of the RTV Guide, it is possible to identify the names of arts and culture programmes broadcast in the early to mid 1960s. The key programme was 'KINO': The World of Film', which ran for short seasons from 1963, while art and culture programmes like 'Spectrum: A programme for the Arts' and more general current affairs programmes 'Broadsheet' and 'Topic at 10' also included items about film and cinema. Some of this broadcast footage survives and provides important insights into film and television culture. Archival resources are supplemented by secondary work on the place of film and television within Ireland in the 1960s, the social and economic determinants which led to the creation of RTÉ as a national broadcaster, as well as the relative absence of an Irish domestic film industry. By utilising a mixed methodology of excavation and scrutiny of surviving archival moving image content, supplementary explorations of TV listings and combined with secondary sources from television, film and cultural history, this research aims to draw together film and television history to address a number of key ideas. Firstly, how were the film and television industries positioning themselves in the period 1960-1965 within a national context? Secondly, how was television showcasing the medium of film both through the broadcast of feature films and through arts and culture programming? Thirdly, what could surviving television archival material tell us about cinema and film culture in the early 1960s? Fourthly, what remains in the archive and what has been lost and what value is this material to the film and TV scholar?

\section{A national broadcaster}


In order to understand the relationship between the film and television industries following the launch of RTÉ, it is important to understand the particular reasons behind the creation of the television channel. Writing in 2004, Farrell Corcoran, recently appointed chairman of the RTÉ authority, wrote retrospectively of RTÉ's purpose. He drew attention to the broadcaster's social role and declared that its responsibility was and always had been, 'to make sense of the society for viewers and listeners, by drawing from the available stock of frameworks and narratives and marking the boundaries of what is permissible. ${ }^{8}$ Corcoran also considered that:

RTÉ provides the dominant pictures of the world by which we make sense of life around us. It has played a major role in dominating the symbolic environment in which Irish people construct their sense of identity and were the 'common sense' that underpins the everyday life of the community. ${ }^{9}$

This dual focus on what was permissible as well as pervading notions of cultural and social identity are crucial to understanding how RTÉ operated in 1960s Ireland. Telefís Éireann began broadcasting on 31 December 1961. The channel was broadcast from $5 \mathrm{pm}$ every day until $11.15 \mathrm{pm}$. The first volume of the RTV Guide, published in early 1962 devotes a great deal of attention to the launch of the channel, including some of the technical issues that marred the first broadcast. The listings guide also includes detail on radio programmes broadcast by RTÉ radio as well as television listings for the BBC. Lance Pettitt suggests that one of the key reasons for the launch of RTÉ broadcasting was that many Irish audiences already had access to overspill signals from the BBC as well as from Ulster TV which launched in the North in 1959. Pettitt argues these reasons "provided the context and incentive for discussions about the desirability of a national broadcaster.'10

Pettitt outlines that the Irish Free State had established its own radio broadcaster in 1926 which became Radio Eireann in 1937 but it was not until the 1960 Act which launched RTÉ that the broadcaster was given a degree of independence from the State. ${ }^{11}$ The decision for the Irish state to fund and launch a broadcaster was not clear-cut. Debates abounded in the Dáil about what model of broadcasting would be most suitable and how the government and important conservative influences like the Catholic church would not be side-lined by the new medium and would retain their influence over Irish society. Martin McLoone has noted three factors which informed 
the inception of the national broadcaster, specifically; the economic and social conservatism of Irish society, the frequently expressed concerns about the possible effects of television on Irish society, and the relationship between the proposed public broadcaster and the state. ${ }^{12}$ McLoone suggests that the isolationist approach pursued by successive Irish governments was beginning to thaw by the end of the 1950 s and that at this moment Ireland began to engage with mainstream European influences. ${ }^{13}$

Yet as John Bowman notes, not everyone was keen for the development of an Irish television service and in 1958, Irish cinema and theatre owners lobbied the government in protest. ${ }^{14}$ He notes:

The society which was about to be exposed to television had been a historically sheltered one. It had further reinforced its isolation by enacting some of the most draconian censorship laws governing print and film in the English-speaking world. The church was an enthusiastic cheerleader, approving the cultural and intellectual isolation of the country. ${ }^{15}$

As Kevin Rockett has highlighted, in Ireland it was less a case of conservative forces seeking to use the power of the media for their own ends, but rather wanting to supress representations of socially divisive topics such as divorce, as well as the pervasion of imported popular media forms. ${ }^{16}$ This was achieved through a powerful alliance of Catholics and Nationalists who ensured that stringent state-sanctioned censorship of print and film within Ireland remained firmly in place and was largely unquestioned. ${ }^{17}$ Film also occupied a dominant cultural space within Ireland. Savage notes that in 1950, annual cinema admissions in Ireland topped 41.6 million and would climb to 54.1 million by $1954 .{ }^{18}$ The same conceptions of acceptability, taboo and permission which governed cinema were also to be rigorously applied to Irish television.

Pettitt suggests that in adopting a modified British model of Public Service Broadcasting, Ireland conformed to 'a tendency towards post-colonial mimicry.'19 While this may have been the case, the model of a broadcaster which was partly funded by the state but which also had a modicum of independence was a pragmatic 
decision. Yet as Savage highlights, from the outset RTÉ's ideological position was compromised. He notes:

The 1960 Broadcasting Act created a service that was given two contradictory objectives. It was required to "serve the nation" by providing educational and cultural programmes and it was responsible for providing popular entertainment that would find a large audience and attract rate paying advertisers. ${ }^{20}$

For Pettitt one of the principal positive outcomes of RTÉ's autonomy was the ability to engage with and report on events in Ireland and the rest of the world, as well as to contribute images of a more modern Ireland. ${ }^{21}$ While this was certainly the case in relation to the rest of the world, RTÉ was actively discouraged from providing coverage or comment on Northern Ireland, amidst fears that such actions would upset the Stormont government. Savage also notes that it was understood that the Broadcaster would treat subjects such as sex, religion or education with sensitivity and care. ${ }^{22}$

This focus on everyday life and notions about Irish cultural and social identity specifically those related to church and community - emerge in a careful examination of early RTÉ content. The programmed content reveals a great deal about the society and its viewers; Sundays are notable for their religious content, the closedown every night often contains a prayer or a 'thought for the day' offered by a religious figure, while the coverage of Easter services in 1962 includes two hours of coverage on Good Friday from 2.30-4.30pm and then closedown for the rest of the evening.

Writing from a modern vantage point, Corcoran pointed out 'when television first arrived in Ireland as a mass medium in 1961 [...] it was often portrayed as a modernizing force, dragging society away from its traditional roots, especially what remained of Gaelic and catholic tradition. ${ }^{23}$ Yet the broadcast listings indicate that far from dragging society away from its traditional roots RTÉ was in fact offering modernity whilst simultaneously drawing attention to tradition. From the outset, RTÉ set out to ensure that its broadcast programme reached all corners of Ireland and addressed the needs and interests of the viewing public. A serial programme 'On the 
Land' was about farming, while a significant number of television magazine programmes focused on aspects of Irish life - a pragmatic choice for a broadcaster eager to produce cheap content which appealed to viewers. It is interesting to see how RTÉ set out to capture the rural as well as the metropolitan viewer. A thoughtful article in the RTV Guide from January 1962 pondered the effect and impact of television on rural viewers. ${ }^{24}$

In the earliest published listings of 1962, many of the letters and articles focus on the importance of television to Ireland. Letters from enthusiastic viewers were published which commended the efforts made to bring television to all parts of the island. One viewer wrote that the reception was 'not bad in Galway', another noted that there was '[a] good picture in Tipperary' while a third celebrated that they had received a decent signal in Belfast. ${ }^{25}$ Perhaps most interesting was the letter from a viewer who enthused that 'we got perfect reception here, 110 miles away [with] both sound and vision just as good as the best cinema screen in Dublin.'26

As with all broadcasters, but particularly those with a national agenda, signal coverage is crucial for success. Pettitt notes that by 1968, RTÉ had extended its coverage to $98 \%$ of the country, a significant achievement which promised well for the future of the broadcaster and attested to its increased popularity and centrality to daily life.$^{27}$ Yet what cultural agenda did the Broadcaster offer to its viewers?

\section{Film and Television}

It is clear from the tone of the articles included in the broadcast guides from 1962 that the grandees of RTÉ were keen for television to be considered as a separate medium from cinema. In an RTV Guide article from April 1962, Gabriel Fallon commented on the investigation taking place across the water in the UK about the influence of television and argued emphatically:

I imagine that in considering the influence of television they will have the wisdom to allow for the fact that most of the influenced ones have already been conditioned by the cinema. That television makes a deeper and more immediate impact that the cinema l'm prepared to agree, but reactions to television will to a great extent be influenced by the lessons we learnt when we went to school to the cinema. ${ }^{28}$ 
Despite attempts to separate the two forms, the film and television industries were engaging directly with one another, although suspicion and hostility characterises the material in the RTV Guide. Despite the foundation of film studios at Ardmore in 1958, an independent, profitable and stable Irish film industry that could supply an endless chain of appropriate - and carefully moderated - content for the cinema-going public did not exist, so cinema in Ireland comprised mainly imported British and Hollywood cinema which had been heavily censored. While the hostility of cinema to the new medium of television can be easily explained in terms of business competition, the absence of a domestic film industry can be ascribed, as Ruth Barton believes, to the continued dominance of Ireland's literary traditions. She writes, 'Irish cinema has struggled to find its own place in a critical environment dominated by the literary.'29 As will later be shown, the decision to appoint literary giant Patrick Kavanagh as RTÉ's resident film critic was more about his stature in the world of literature than from any knowledge or indeed of desire to write about film and cinema.

McLoone suggests that 'the dominance of a rich literary and dramatic culture reverberates through all areas of the arts and education in Ireland' and such preoccupations are evident from the outset in the programmes broadcast on RTÉ. ${ }^{30}$ Throughout 1962, magazine programme 'Spectrum: A programme for the Arts' was broadcast on Thursdays at 10.30pm. Produced by Jim FitzGerald 'Spectrum' had a broad arts and culture remit with episodes focusing on dance and ballet, on poetry and in its Christmas episode broadcast on 27 December, on paintings of nativity scenes. ${ }^{31}$ Gabriel Fallon wrote fulsomely that 'Spectrum is a programme which, more than any I have seen, make me feel that Ireland has a particular and a particularly fine contribution to make to television. It is also a first-class example of bringing art to the people - the right people.' 32

Explorations and discussion of national art and culture permeate the early days of RTÉ's programming. Yet the issue of an Irish film industry, although consistently explored, is unresolved at the start of the 1960s and a programme devoted to film and cinema is absent from the listings for the first year of broadcast. Current affairs programme 'Topic at 10' focused its edition of $1^{\text {st }}$ June 1962 on the question of the Irish Film Industry. Chaired by the host of RTÉ's religious discussion programme 'Enquiring Minds', Maxwell Sweeney, the panellists included Harry Cush, President 
of the Theatre and Cinema Association, Justin Collins, General Manager of Ardmore Studios, and JB Kelly, Secretary of the Cinema and Theatre Branch. ${ }^{33}$ Though this programme does not survive in the archive, an article to accompany the programme remains in the RTV Guide. Due to the absence of the programme, it is worth quoting here in detail. Within this piece the un-named author writes:

Idealists have been urging the establishment of an Irish film industry for many years, but idealism and the necessary finance for filmmaking are rarely to be found in the same briefcase. Filmmaking is becoming increasingly international, there are more and more co-productions going before the cameras in Europe - it is one way of ensuring a bigger distribution of a picture, and distribution is important if a picture is to recover its costs. For Ireland there may be an opportunity of cooperating in such productions, particularly in the common market era, but there is no use pretending that the pictures which have been made here up to this time represent an Irish film industry. ${ }^{34}$

Here the twin issues are those that plague all national film industries; finance and national identity. The question of how an Irish film industry would be funded is important for RTÉ as any state subsidy of film would have implications for the national broadcaster, yet as will be shown here, RTÉ was specifically positioned to be entirely separate from the film industry. The secondary issue is that of content, specifically what kind of films should an Irish film industry be making and how were these films to be representative of Ireland as a nation? The mention of co-production hints at fascinating European opportunities, yet Ireland would not join the EEC until 1973 and so such opportunities for the 1960s are limited. The most obvious collaborators for Ireland would be Britain and America, yet how to achieve effective collaboration without diluting Ireland's national heritage? The article goes on to suggest:

Enthusiasts point to the great Irish sagas of long ago as ideal material for filmmakers. Some of the stories are great romances, and the battles were thrilling. They excite us because we are familiar with the stories but... the Irish audience just can't pay the cost of making big pictures. The income from showing films in this country is comparatively small, certainly not nearly enough to pay for a well-made production of Diarmuid and Grainne. Would these stories excite overseas audiences? It is essential that they should if the film is to 'break even'. And then the audience in Britain, America or Hong Kong is not interested in our past; they are not interested in the drama of our history - they are interested in lavish -coloured spectacle and are not particularly concerned whether it happens in Tibet or Tyhagh. ${ }^{35}$ 
The influence of Hollywood and to a lesser extent Britain, shaped, informed, reflected and influenced the cultural images which came to signify Ireland across the globe. As Barton contends, the absence of a local film production industry meant, 'if we are to talk of a national cinema, or a national film text even, we have to engage in a series of acts of creative bricolage; that is to see how an image of Ireland on screen emerged out of the notional industries of other countries. ${ }^{36}$

Yet despite the potency and power of the cinematic image, in the early years of RTÉ, the broadcaster paid much more attention to its literary and theatrical heritage and used this material, more so than cinematic representations, to situate its own programmes. Following its launch, RTÉ's Head of Drama suggested that TV drama was fundamentally different to the cinema as it was rooted in the theatre, while columnist and critic Gabriel Fallon who would later become a deputy film censor, argued for the importance and distinctiveness of television as a medium claiming; 'there is that about television which makes it a more powerful persuader than the cinema. It seems to have a greater reality. ${ }^{37}$

It is clear that television in Ireland is intended to be entirely different from cinema. This positioning of the two forms effectively mirrors the UK, where in the 1950s television was being heavily subsidised by the state while the floundering film industry was expected to be commercial successful and culturally viable. In a comparison of the two UK industries, Barber has shown how film and television were ideologically conceived differently and this had a fundamental impact on their cultural form and function. ${ }^{38}$ In the 1960s, the British film industry was propped up with American investment which effectively underwrote many of the critical and commercial successes of the decade including Billy Liar (1963), Darling (1965) and Tom Jones (1963) as well as the developing James Bond franchise.

What is perhaps significant about the creation of RTÉ is that while arguments were being made for the distinctiveness of the Irish television broadcaster, and its separateness from film and cinema, a great deal of its content was not domestically produced but rather imported from the US. Flynn's exploration of the content on RTÉ in the years 1962-1966 has identified that bought in American sit-coms, westerns and anthology dramas, many of them already a few years old, were the cheapest 
option for the broadcaster and so dominated the scheduled programming and effectively shut out domestic production. ${ }^{39}$ Christopher Morash goes further declaring 'without American television, there would have been no Irish television' with US networks accounting for roughly half of everything broadcast on RTÉ. 40

In a decade noted for its cinematic realism in the form of kitchen sink drama and domestic new wave cinema typified in the French, British, Czech and Polish new waves, by contrast Irish television was populated by material which offered a vision of American modernity. As Morash notes, 'American programmes introduced into Irish life a kind of belated modernity putting Irish people within sight of a shiny new world that already slightly out of date. ${ }^{41}$ This time-lag reality of westerns, light comedies and sitcoms which formed the backbone of RTÉ content throughout the 1960s, was echoed in the film content broadcast on the channel. In an era of mass cinema attendance, the films on offer within the cinemas of Ireland were subject to the heavy censorship of the national censorship board who were keen to ensure that standards of morality were maintained. As Kevin Rockett has identified, the strict censorship of film in Ireland had been well established since the 1920s and the involvement of an Irish Film censor at RTÉ to police all film content was an accepted part of the operation. ${ }^{42}$

Rockett quotes Telefis Eireann's Head of Management who clarified RTÉ policy on film broadcasts on television:

Every piece of film is previewed and passed before being shown. Censorship is the [television] authority's own responsibility but a close liaison has in fact been established with the censorship of films office and this has been found to be of benefit in cases of difficulty. ${ }^{43}$

But the censorship of films on television by the Irish Censorship Board could still be circumnavigated by the viewers. As Rockett reminds us, the overspill television signals from BBC and ITV channels broadcasting from Britain and Northern Ireland allowed Irish audiences to view film material on television which had not been cleared by the Irish censor. ${ }^{44}$ While Irish cinema was neglecting to engage with more up to date material from across Europe and North America, films do play a significant part in the early broadcast material of RTÉ. They feature alongside news 
programmes, gameshows and a children's corner but tend to be Hollywood films from the 1930s, predominantly melodramas, comedies and westerns.

As well as the enduring conservatism of Irish society, the reasons for programming older films can be explained by the decision of Hollywood studios to sell off their back catalogues. As Bowman identifies, this action was undertaken by RKO, Warner Bros., $20^{\text {th }}$ Century Fox, Paramount, Columbia and Universal who all offloaded their libraries of old films made before 1948. These films were owned outright by the studios and therefore required no residual payments to be made to those involved in the original productions. ${ }^{45}$ Such action by the Hollywood majors generated a quick profit, but also ensured that the burgeoning medium of television was heavily supplied with Hollywood product. As Bowman notes, securing the Irish rights to these films for broadcast on television was both straightforward and cheap, but there was a further reason why films from this period were bought by the national broadcaster. All of the material contained within these films was covered by the Hays Code and thus unlikely to offend or scandalise Irish audiences.

A survey of the kind of films shown on RTÉ in the early 1960s indicates that there was little likely to offend. For example, the listings from January 1965 include showings of Stage Door (1937) a backstage drama starring Ginger Rogers and Katherine Hepburn, Road to Zanzibar (1941) with Bob Hope, Bing Crosby and Dorothy Lamour, State of the Union (1948) with Katherine Hepburn and Spencer Tracey, and The Big Clock (1948) a crime thriller starring Ray Milland, Maureen O' Sullivan and Charles Laughton. ${ }^{46}$

Yet this dominance of Hollywood film on RTÉ only became established a few years after the launch of the channel. A careful perusal of the early days of broadcaster indicate some different trends and some more innovative programming. For example, in 1962, the first year of transmission acclaimed film documentary Nanook of the North (1922) was broadcast on Wednesday 10 October at 9pm, while on Friday 9 February in the same year, a series of films made under the fledgling Radharc label focusing on ritual baptism and marriage were shown. ${ }^{47}$ As John Horgan has identified, the creation of the Radharc label was the result of powerplay between the broadcaster and the Archbishop of Dublin. ${ }^{48}$ Confident that his choice, Fr Joe Dunn, 
would be chosen as religious as advisor for RTÉ, the Archbishop, Dr McQuaid, ensured that Dunn received full training as a filmmaker. When Dunn was not selected, he founded Radharc, recruited and trained clerical and lay filmmakers, and embarked on the production of a series of documentaries exploring aspects of religious and secular life. Radharc films were a significant part of RTÉ broadcast for three decades and as Morash has identified, while many of the films explored religious issues, others 'opened up social issues in ways that had not been seen before on Irish television, in films such as Down and Out in Dublin (1964) Smuggling and Smugglers (1965) and Open Port (1968) which dealt with prostitution in Cork.'49 These short films have been carefully preserved by the Radharc organisation, and a full list of programmes, as well as extracts from the films, is available on their own website. ${ }^{50}$

For RTÉ, amateur and religious filmmaking is a significant part of their output in these early years with missionary films and religious films regularly screened on Fridays. There are also a number of short films being shown including the seasonal short Amelia and the Angel (1958) made by British director Ken Russell and broadcast as part of the Christmas programming on 24 December at $10.45 \mathrm{pm}$. Finally, Saturday night programming in early 1962 sees a range of silent films including The Three Musketeers (1921) with Douglas Fairbanks Senior and The Eagle (1925) starring Rudolph Valentino.

As well as the screening of films, RTÉ also offered the opportunity for discussions about film and cinema. In addition to programmes which debated issues related to film and cinema, the RTV Guide also provided a space for discourse around film and cinema to be articulated. The Guide listed the weekly programmes but also included articles, reviews, letters and features about the programmes as well as current affairs, music and popular culture. In later years there would be ready made programmes about the history of film bought in to fill the schedules, but in this early period, as already shown, one of the enduring topics for current affairs programming was the absence of a domestic film industry. However, by the end of 1962, it was clear that something was missing and that that RTÉ viewers wanted a reviews programme about film which offered a space for discussions about cinema. 


\section{Debates about cinema: Arts and Culture programming}

The launch of 'KINO': The World of Film' in 1963 offered television viewers reviews of the latest cinema releases as well as clips and interviews with stars and directors. "KINO" was broadcast at 10.30pm on a Tuesday (later shifted to a Thursday) and was described in its inaugural programme as 'the first in a series of fortnightly programmes for filmgoers. Frank Ryan presents excerpts from current releases and brings you some of the interesting people in pictures. ${ }^{51}$

Much of the 'KINO' material no longer remains, but fragments of the programme's interviews and reviews can be traced in the RTÉ archive. Stored on a range of tapes and in a range of formats, they include some fascinating material. The focus of the programme and its approach to film and cinema can be pieced together from these fragments as well as the information provided in the broadcast listing which indicates what the programme would cover that week. Produced by W.F Harpur and directed by Michael Monaghan, the first 'KINO' programme in January 1963 included an interview with Basil Deardon, director of melodrama Life for Ruth (1962) as well as reviews of American noir Grip of Fear (1962) with Glenn Ford and Lee Remick, The Phantom of the Opera (1962) from the Hammer film studio, and riotous British comedy We Joined the Navy (1962) directed by Wendy Toye. ${ }^{52}$

The programme was welcomed enthusiastically by author of the RTV Guide's 'Critics view' Gabriel Fallon. He wrote fulsomely:

A very hearty welcome to 'KINO' which was first requested in this column some months ago. We badly needed this contact with the world of cinema and to judge by a first showing, we have just the right people to make that contact for us. As one who has always favoured co-operation, I am pleased to note that both the Irish Film Society and the National Film Institute are working together on this programme. ${ }^{53}$

As well as offering reviews of current releases, 'KINO' also offered insights into the history of cinema and the development of film as a form. The programme broadcast on 29 January includes an exploration of the film A Question of Time, which was made by the pupils of St McNisuss College, County Antrim and which won an award from the National Film Institute, while the programme broadcast on Thursday 12 
February focused on the early history of moving image. ${ }^{54}$ The RTV Guide write-up of the forthcoming programme details:

John Huntley of the BFI tells how moving pictures were first made and illustrates his talk with a showing of Lumiere Cinematograph, the very first film show which was first presented in Dublin in 1896 at the Olympic Theatre. ${ }^{55}$

These forays into the history of cinema as well as the championing of local amateur filmmaking reveals a broad remit for 'KINO' and an attempt to engage television viewers with film on a range of levels. Yet 'KINO' attracted criticism in the pages of the RTV Guide only months after its launch with Fallon castigating the programme and its makers for failing to live up to expectations. He wrote on 22 February,

A word of warning to 'KINO'. When I suggested here that a film magazine on TE might do much to make us better, i.e. more perceptive cinema goers, I had in mind a programme which would be in the main consistently critical. Some of "KINO"s items are fulfilling this purpose very well indeed but not enough of them. There is a tendency to give too much room to what I call manufacturers blurbs. A recent interview with this intent made it only too clear that the interviewed 'star' was just as bored as we were. ${ }^{56}$

Such stringent criticisms for a programme launched only a few months before seems out of place, yet suggest a great deal about how Fallon, writing in a critical capacity for RTÉ, felt about programmes about cinema and what 'KINO' should be covering. It also indicates the levels of cultural discourse surrounding the two media forms in Ireland.

Perhaps partially in response to this criticism, by May 1963 the RTV Guide had a film critic; writer, poet and raconteur Patrick Kavanagh. A familiar figure in the literary world, and an important part of Ireland's literary heritage, Kavanagh was totally unsuited to the role of film reviewer. His columns ran from 1963 to 1967 and are a master class of fascinating meanderings and amusing anecdotes. Kavanagh was not interested in film or the cinema and was completely unfamiliar with critiquing films. His columns often contain only a brief reference to films and in many cases the films he does mention are older productions and not current releases. 
In his column of 9 August 1963, Kavanagh does mention watching two recent releases, Lawrence of Arabia (1962) and A Long Day's Journey into Night (1962) but he does not reflect on either of the films as visual objects, but rather as adaptations of literary works. He states that he has never read the book on which Lawrence of Arabia is based and subsequently dismissed the film production, but offers a hearty evaluation of A Long Day's Journey into Night based solely on the literary merits of O'Neill's original play. This refusal of the guide film critic to offer critiques of films did not go unnoticed by readers or viewers. A letter from 10 May 1963, pleaded, 'please let's have a film page in the RTV Guide but get some young man with an up to date film knowledge to write it. We film fans want to know what's going on now, not what went on in Mr Kavanagh's hey day. ${ }^{57}$ Another letter from August 1963 pointed out, 'Patrick Kavanagh is supposed to be film critic for the RTV Guide. As far as I can see, the last time he was at a film was when Rudolph Valentino was around, which wasn't today or yesterday. So please get rid of Patrick Kavanagh. ${ }^{58}$ A further letter from October 1963 wondered, 'when are you going to give us a film column deserving of this title? Patrick Kavanagh is neither informed nor interested in the cinema to write this type of page. ${ }^{.59}$

Kavanagh's obvious lack of interest in the cinema and his disdain for film as a cultural form was clearly disappointing to many readers and viewers. As well as distancing himself from contemporary film and cinema, Kavanagh also failed to recognise filmmaking or cinema as either art or culture. In his column for January 1964, he wrote:

Another new book on the cinema business is Film: An Anthology. Although I have enjoyed many films, I have never been able to take the film...in the ponderous serious way that these writers take them. It is by meeting the directors that one loses belief in the possible genius of the films they make. In fact, I know that a large percentage of film directors dislike any connection with true creativity. Stupid superficial fellows and the next thing you hear is that they have made a masterpiece..$^{60}$

Kavanagh's views on film contrast sharply with much of the other writing on cinema contained in the guide and also with those responsible for producing 'KINO' which offered a more enthusiastic critique of film culture. The 4 June edition of the programme included a report on the Cannes Film Festival (which Kavanagh did not 
attend), and interviews with Richard Harris, Gregory Peck and Britain's top female Director Wendy Toye. ${ }^{61}$ Unlike Kavanagh who had nothing positive to say about Harris, mentioning only, 'I wish I could say something positive about This Sporting Life for the star is from Limerick and well known in Dublin', 'KINO' recognised the importance of Harris' work and referred to him in the synopsis in the RTV Guide as 'star of the outstanding film 'This Sporting Life.'62

While it is perhaps not unusual for the 'KINO' programme to offer a contrasting view to the resident film critic, what is perhaps surprising is the TV guide itself offering contrasting views on film and cinema within its own pages. Back in February 1963, the guide had featured 'KINO' on its cover and included a lengthy article about the making of Mutiny on the Bounty (1962) which starred Irish actors Richard Harris and Noel Purcell. The article written by Graham Sennett notes, 'Harris, the Limerick-born former Rugby player is cast as John Mills, the leader of the below deck mutineers. Harris has been an actor since he left school. He will soon be seen as a professional Rugby player in This Sporting Life.' ${ }^{\prime} 3$

This is not an isolated incident. The RTV Guide for Tuesday 27 August includes a full page write up of one of the films to be reviewed on 'KINO' that week, Tony Richardson's The Loneliness of The Long Distance Runner (1962). The feature article notes:

Directed by Tony Richardson, Britain's top young director. Richardson, whose passion for realism causes him to shoot all his films on location and to use established stars only when he has to, has discovered some of Britain's best young stars including Albert Finney. Rita Tushingham, Tom Courtenay, Murray Melvin and others. ${ }^{64}$

Such awareness of the films of the British New Wave and of this particular film indicates that someone involved in the RTV Guide appreciates and recognises their importance. By contrast, in his film review column for this week, Kavanagh describes his trip to the cinema to see The Punch and Judy Show (1963) with comedian Tony Hancock and a Laurel and Hardy rerun. Kavanagh was unrelenting in his dislike of the films of the New Wave and of contemporary cinema; he considered these films depressing and not really worthy of critique. His review of $A$ Kind of Loving (1962) 
noted only '[the film] came down from the Black English Midlands and that was the poor kind of loving. ${ }^{65}$ Even the raucous and colourful Tom Jones (1963) did not meet with his approval; he hated the film and was unimpressed by Albert Finney in the titular role, though he does admit that he has not read the Fielding novel on which the film is based. 66

By the end of the summer of 1963, 'KINO' had finished its broadcast run and its regular slot was now occupied by a quiz programme called 'Celtic Challenge' in which well known personalities are challenged by teams of students on topics of general interest. ${ }^{67}$ In October 'KINO' returned to RTÉ and had been reconfigured as an hour-long programme which would be broadcast at $10 \mathrm{pm}$ every Wednesday. Its first programme covered the Cork Film Festival and much of the visual material from 'KINO' which survives in the RTÉ archives pertains directly to the 1963 festival. The final part of this article will focus upon what the surviving archival material reveals about the relationship between film and television culture in this period.

\section{Case Study: RTÉ, 'KINO' and the Cork Film Festival}

In late September 1963 the RTV Guide promoted some of the films which would be shown at the upcoming $8^{\text {th }}$ Cork Film Festival. Images of films including Lullaby with Judy Cannon and The Leather Boys (1964) accompanied the usual critical column from Patrick Kavanagh. Kavanagh's column does not mention any of these films, but instead focuses on the upcoming festival and the city of Cork though he makes it clear that he is not planning on attending the festival. The Guide indicates that the 'KINO' programme of 10 October will include a report from the Cork Film festival, but does not detail what will be included.

While only a small portion of material pertaining to film or cinema was identified using keyword searches in the RTÉ internal catalogue, searches for Cork Film festival were more productive. The archive catalogue is intended for internal use and so finding fragments of a particular programme that has undergone numerous name changes throughout its years of broadcast is hugely challenging and often requires the help of in-house staff to locate material. The material is also preserved in a range of formats and often added to empty space at the end of other programmes, sport and nonbroadcast footage. This material was often subtitled 'world of film' and by matching 
its content to the content described in the RTV Guide, we can tentatively assume that some of the recorded material from the 1963 festival contributed to 'KINO's' output in the months that followed. Material identified comprises interviews with stars and directors, many of whom had films being shown at the festival as well as discussion programmes associated with particular issues. This material appears to have been shot in various hotel rooms without an audience, and were presumably not part of scheduled festival events but rather recorded specifically for broadcast on RTÉ.

The first programme of interest is a recorded nine minute interview conversation between Edgar Anstey, a British film director and producer who worked on the British Transport Commission films and Father Johnny Burke of the International Catholic Film Office. ${ }^{68}$ Catalogued as 'Cork Film Festival 1963, World of Film', there is no mention of 'KINO', yet the interview subjects are introduced by Kevin O'Kelly, an oncamera 'KINO' interviewer. In a thoughtful introduction, O'Kelly suggests that recent films from the British New Wave as well as associated films such as John Schlesinger's Billy Liar (1963) use cinematic realism to address the 'hard drama of daily life.' Anstey suggests that these films are not so much about the 'sordid aspect of life' but rather the more vicious side of human behaviour. He Uses Billy Liar as an example and observes, 'film is an invitation to surrender ones sense of social responsibility and to give way to the feeling that man is an inadequate sinner and there is little to be done about his state.' Both men agree that many of these films including A Kind of Loving (1962) - are profoundly religious in nature, but that they offer conclusions which are 'gloomy, nihilistic, pessimistic.' What is fascinating is how they both agree that the British New Wave - and its associated films - is a kind of filmmaking which is full of compassion and as such is determined to say something significant. Throughout the interview, a number of films are briefly discussed, and, perhaps contrary to the heavy censorship imposed on film dealing with challenging issues in conservative, Catholic Ireland, there is no discussion about the content of these films being controversial. Even A Taste of Honey (1961) - a film which deals with illegitimacy, teenage pregnancy, alcoholism, homosexuality and a mixed-race relationship - is discussed thoughtfully, and Father Burke concludes that $A$ Kind of Loving with its central focus on pre-marital sex, is in fact 'saturated with compassion' and could be termed, 'a religious film.' 
Here we can see that despite the controversial content of much New Wave cinema, and the refusal of the Irish Film Board to show these films without significant cuts, serious conversations about them were taking place within Ireland. This interview was recorded by RTÉ and catalogued as part of the Cork Film festival footage and yet there is no clear indication where it will be broadcast. The inclusion of Kevin O'Kelly suggests that it will form part of the 'KINO' programme, yet the broadcast listing from 1963 simply states that the 'KINO' programme of 10 October 1963 will include a report from the Cork Film festival. It is unlikely that this interview would have been broadcast in its entirety as part of this programme, but it is possible that it was included in later programmes of the series, perhaps those that discussed Billy Liar when the film was on general release in Ireland in 1964. The RTV Guide for Friday 7 February includes a promotion of the upcoming 'KINO' programme and describes its contents thus:

The illusory dream world of Billy Liar will be discussed and some extracts from the film shown in 'KINO' on Thursday at 10.15. Tom Courtenay who plays the title role gave a performance that drew high praise from the British critics. Irish critics and audiences will shortly have the opportunity to make up their own minds on that score when the film opens here. ${ }^{69}$

This would seem to indicate where this particular interview would fit, however the RTV Guide describes the interviews which will contribute to this programme as being with director John Schlesinger and actress Liz Fraser, star of Carry on Cabby. There is no mention at all of either Anstey or Burke, yet surely this fascinating interview would have been included as part of an RTÉ programme?

A second interview with Swedish actress Mai Zetterling runs for 11 and a half minutes and covers a number of topics including Swedish, British and American filmmaking, and the scarcity of interesting parts for women in New Wave cinema. It is catalogued as being part of 'KINO' and recorded as part of the Cork Film Festival in 1963, and the off-camera interviewer is again listed as Kevin O'Kelly. ${ }^{70}$

The interview is revealing and the thoughtful, mischievous and engaging Zetterling is an excellent subject, offering thoughts on cinema, on filmmaking practices, on the role of prominent directors, notably on Bergman's importance within Sweden and on 
her own career. Unfailing polite she nevertheless challenges the interviewer when he seeks to glibly position her as a global film star - pointing out that she has only actually made films in a very few countries - and refusing to discuss the foibles or idiosyncrasies of her famous co-stars who have included Peter Sellers. What are most interesting are her thoughts on gender and the film industry: she cites the demands made upon women by Hollywood and comments that she did not want to be the 'cheesecake' often required by studios and later confirms that this was the reason for her withdrawal from Hollywood films. In response to the interviewer's questions she agrees that the British New Wave films are exciting yet there is very little in them for women to do. She observes:

England is very much a man's country, a man's world and man's films are being made. [in British New Wave cinema] three parts are available to women, the dear wife who sits and home and waits for the husband, mends the socks, Celia Johnson. And then the secretary, quite efficient, perhaps the mistress of the boss, very nice, very efficient and then of course the tart - usually played by a continental lady. But then perhaps, a woman of flesh and blood, I don't know.

The interviewer then wonders if English directors perhaps don't understand women, a point which Zetterling concedes with a wry smile, but then she suggests that with the emergence of directors like Tony Richardson, the situation may improve. The second part of the interview is concerned with her own filmmaking and her work in the field of documentaries for television as well as her short film The War Game (1963) which is being shown at the Cork festival. The whole interview is full of interesting thoughts and observations- not just upon the practices and processes of filmmaking - but where film and filmmaking is at this precise moment in the early 1960s. Cross referencing this interview with the synopsis of the 'KINO' programme recorded in the RTV Guide reveals that on Thursday 27 February 1964 the broadcast programme will include:

A special feature on tonight's programme deals with the short British film The War Game. Kevin O'Kelly interviews its producer Mai Zetterling and Branche Cecil will be in the studio to talk about her nephew lan Ellis who is one of the young actors in the film, and to tell us something about her fascinating job as a chaperone top juvenile performers in British pictures. ${ }^{71}$ 
It is unlikely that two interviews with Zetterling were conducted, and yet this synopsis suggests that the interview relates to Zetterling's film The War Game. However, discussion of this production occupies only the final three minutes of the 11 and a half minute clip. The rest of the interview is concerned with a much broader range of topics. The tantalising question which emerges is how much of the interview was broadcast? The 'KINO' programme ran for 55 minutes and as well as the interview with Zetterling there were also clips from new films listed including Rampage (1963), The List of Adrian Messenger (1963) and The Trial of Joan of Arc (1962) plus the instudio interview with Branche Cecil. It certainly appears that the recording of the Zetterling interview is the unedited version of the full interview and it remains unclear how much would have been included in this short programme.

A third interview from the archives is with filmmaker Paul Rotha. ${ }^{72}$ Again catalogued as part of the 1963 Cork film festival, this material is particularly confusing. If it was indeed recorded as part of the festival footage in 1963 - and a connection with the festival is evident on the tape which includes silent stock footage of Cork city - a description of an interview with Rotha is included as part of the 'KINO' programme from 18 June 1963 - four months before the festival took place. Either this is an incorrect cataloguing of the visual material (perhaps from the festival of 1962 not 1963) perhaps it is an error in the RTV Guide from 1963, or maybe two separate 'KINO' programmes included excerpts of the interview with Rotha. As with much exploration of archival broadcast footage it is often difficult to establish what was broadcast and what was not.

The interview itself is 19 minutes long and Rotha discusses a number of specific topics at length with the interviewer. He is particularly emphatic about his dislike of the big film festivals where the focus is on glamour and having to dress up for screenings, but he reveals that he likes the atmosphere and 'integrity' of the film festival in Cork. The two topics which are discussed in detail are both film projects, the first being his documentary production of The Life of Adolf Hitler (1961) which drew extensively on newsreel footage. The discussion of this film lasts around seven minutes and explores notions of authenticity in filmmaking, particular when it comes to using newsreels. He also explicitly states that he wanted this film to be controversial and for it to raise as many questions as possible. The second topic 
which is covered in depth in the interview is Rotha's desire to make a film about Frank O'Connor, a political project with the working title of 'Jumbo's Wife' which will focus on the IRA in the 1920s with proposed filming to take place in Cork and casting of Cyril Cusack and Constance Smith in key roles. Despite Rotha's obvious commitment to this project, there is no evidence that this film was ever made. Other material which deserves critical attention includes a thoughtful interview with Producer Raymond Stross dated 1 January 1964, whose film The Leather Boys was being shown at the 1963 Cork film festival. Stross speaks briefly about making the film, and his career in the film industry but the main body of the interview is concerned with working conditions in the modern industry, specifically the impact of the trade unions (with Stross declaring that 'it was a damned healthy industry before the unions came along'), as well as the importance of European quotas and the need for reciprocal arrangements for Britain. This portion of the interview is fascinating as the discussion turns to how films are funded. In response to a careless question about the financial (and perhaps un-creative) responsibilities of the producer in the filmmaking process, Stross asserts the creativity inherent in the role of producer, maintaining, 'once we get on the floor itself it's in his [directors'] hands, but until we get there, it is in my hands.' Stross also reflects on his own career - in a way which echoes the Zetterling interview - and considers that of his 24 or 26 pictures, there are three that he is extremely proud of, three which are pretty good and the rest were simply 'not what he wanted.'

Other interviews which emerge from the archive which are worthy of mention here are those with Christopher Lee and Richard Harris recorded as part of the programme 'Newsbeat. ${ }^{73}$ In his interview Irish-born Harris discusses his career and argues with the interviewer about his 'overnight success' pointing out he has been an actor for a while, while also defending his decision to delay the christening of his son in County Clare. By contrast, Christopher Lee prefers to discuss monsters in horror films and the importance of gaining the audience's sympathy when playing monstrous characters. He also reflects on the nature of cinema as entertainment, suggesting 'people go to the cinema to be entertained - they like to be thrilled. It gives them a tremendous outlet for their emotions.' There are also brief interviews with other luminaries of British cinema including Rita Tushingham, Vanessa 
Redgrave and Peter Finch, though the audio quality of this collection of the recorded material is very poor and much of the recording hard to hear.

\section{Conclusion}

This preliminary exploration of RTÉ archive material from the early 1960s has indicated an overlap, hitherto unacknowledged, between film and television in Ireland in this period. The material identified reveals a myriad of different ways in which film content is emerging on television, with screenings of older Hollywood films the most obvious but more nuanced discussions of contemporary film culture are also evident. The festival scene, roles within the industry, activities of trade unions, the impact of European production and co-production, issues of morality, gender on the screen, women behind the camera, use of historical material within feature films and notions of controversy are all being vigorously discussed within RTÉ programmes and the RTV Guide.

Contrary to firmly established views about the conservatism of Irish exhibitors and the stringent censorship of cinema within the 1960s decade, as an exhibition space, RTÉ was making a valuable contribution to the world of film. Despite the Hollywood and nostalgia-infused films scheduled by RTÉ as part of its output, the broadcaster was simultaneously attempting to engage some of its viewers in a more informed, critical debate about contemporary cinema, film culture and aesthetics, as well as the more contentious aspects of film production and reception. From discussions of New Wave cinema, championing of younger stars, recognising the issues raised by industrial practices and critiquing more adventurous work as part of 'KINO', such as Last Year in Marienbad (1961) and Cleo from 5-7 (1962), there is far more to RTÉ's approach to cinema than simply a place to broadcast old Hollywood films. ${ }^{74}$ And limiting explorations of RTÉ's engagement with film to a discussion of the film's selected for broadcast actually obscures the more nuanced relationship the broadcaster had with film culture.

Without full surviving 'KINO' programmes it is impossible to know precisely what tone and manner of address was used in their presentation; were the intricacies of film language, style and narrative being discussed? Did the reviews included operate to inform television viewers of new releases and offer up to date information about 
screenings and production? And can they be placed alongside cinema listings or newspaper film reviews to offer develop understanding of film exhibition in Ireland? Certainly the quality of the content evidenced by the small sample of archive material identified here, suggests a high level of engagement with film as a cultural form, a medium in its own right, as both commerce and entertainment, and as an indicator of personal, social and national identity. The approach offered here of exploring the fragments of archival footage that remain and supplementing them with the RTV Guide listings indicates a way to begin. Yet further work is needed to offer a broader and more detailed understanding of RTÉ's involvement with wider visual culture.

A fuller exploration of RTÉ archive holdings could unearth production or programme files while interviews with surviving programme-makers and contributors could provide information about recording and broadcast, as well as the specific technology used. Accessing memories from those involved with RTE, including presenters such as Gay Byrne could also offer useful supplementary information. Perhaps beginning with film rather than with television sources could also be fruitful, for example accessing material held at the Irish film Board or the British Film Institute and using such material to develop a comparative study between British and Irish broadcasters and their engagement with film culture.

This work has indicated a level of interconnectedness of film and television culture in Ireland in this period that has been under researched or downplayed in existing accounts of Irish TV history. The focus on RTÉ's own output, and the centrality of imported US programming, as well as explorations of the broadcaster's political, cultural and ideological ethos has dominated, and as a result, film-related output has been overlooked. Using television archives to explore and dissect debates about film culture, and following on from work undertaken on the BBC, ITV and Channel 4, enables film and television scholars to challenge rhetoric which emphasises the separateness of film and television in 1960s Ireland. A great deal remains to be done, but this preliminary work has indicated the wealth of material within the RTÉ archives and how they can be used to explore film culture in this, and perhaps other periods. Further work is needed to delve more deeply, to recover more fragments of these almost forgotten programmes, to explore the debates and the technology developed, and to trace developments in the years that followed. 


\section{Acknowledgements}

This work was made possible by a television studies grant from FIAT/IFTA awarded in 2015. I also owe my thanks to Liam Wylie and his colleagues at RTÉ archives who generously gave me their time and their expertise.

\section{Notes:}

\section{Primary source material}

RTV Guide 1962-1965 accessed from National Library, Dublin and RTÉ Archives.

\section{Visual material accessed from RTÉ archives, Dublin}

D0304: "KINO'; Geraldine FitzGerald interview from 1963

D0575: "KINO" Eddie Byrne interview from 1963

D0790: "KINO" Andrew and Virginia Stone

D1121: "KINO" Raymond Stross

D1134: "KINO" Liz Fraser interview

DLX/00030: "KINO", Paul Rotha interview from 1963

DLX/00031: Cork Film Festival 1963

DLX/00031: Cork Film Festival tape plus 'World of Film'.

DLX/01048: 'Newsbeat' Christopher Lee interview

DLX/01048: 'Newsbeat' Richard Harris interview

DLX/01719: "KINO" rushes, interviews various

LX003: "KINO" special on W.C Fields

LX2181: 'Broadsheet' Cork Film festival 1963 (8 $8^{\text {th }}$ festival)

LX3201: "KINO", Mai Zetterling interview from Cork Film festival of 1963

LX3992 Broadsheet: 'The Quare Fella'at Kilmainham

A thank you to ...

\footnotetext{
${ }^{1}$ Su Holmes British Television and Film Culture in the 1950s (Bristol: Intellect, 2005)

${ }^{2}$ Mary Irwin, 'Monitor: The Creation of the Television Arts Documentary' 2011 Journal of British Cinema and Television 8 (3): pp. 322-336; John Walker, Arts TV: A History of Arts Television in Britain (London: John Libbey, 1993), AHRC funded project on The History of Forgotten Television Drama in the UK led by John Hill.

${ }^{3}$ Laura Mayne, 'Creative Commissioning': Examining the Regional Aesthetic in the Work of Channel 4's First Commissioning Editor for Fiction, David Rose' 2012, Journal of British Cinema and Television 9 (1): pp. 40-57.

${ }^{4}$ John Bowman, Window and Mirror: RTÉ Television 1961-2011 (Cork: The Collins Press, 2011), Robert Savage, A loss of innocence: Television and Irish Society 1960-1972

(Manchester: MUP, 2010) Christopher Morash A History of the Media in Ireland (Cambridge, Cambridge University Press, 2010), Martin McLoone and John MacMahon Television and Irish society: 21 years of Irish Television (Dublin: TRE/IFI Publication, 1984).

${ }^{5}$ Lance Pettitt, Screening Ireland: Film and Television representation (Manchester: MUP, 2000), Ruth Barton Irish National Cinema (Routledge: London, 2004).

${ }^{6}$ Roddy Flynn "It is against the basic concepts of good government to subject our people to Rosemary Clooney at the public expense': Imported programming on early Irish television.' Eire-Ireland 50: 1 \& 2, Spr / Sum 2015 pp. 66-94.

${ }^{7}$ McLoone 'p. 9.

${ }^{8}$ Farrell Corcoran, RTÉ and the globalization of Irish Television (Bristol: Intellect, 2004), p. 1.

${ }^{9}$ Corcoran, p. 1.
} 


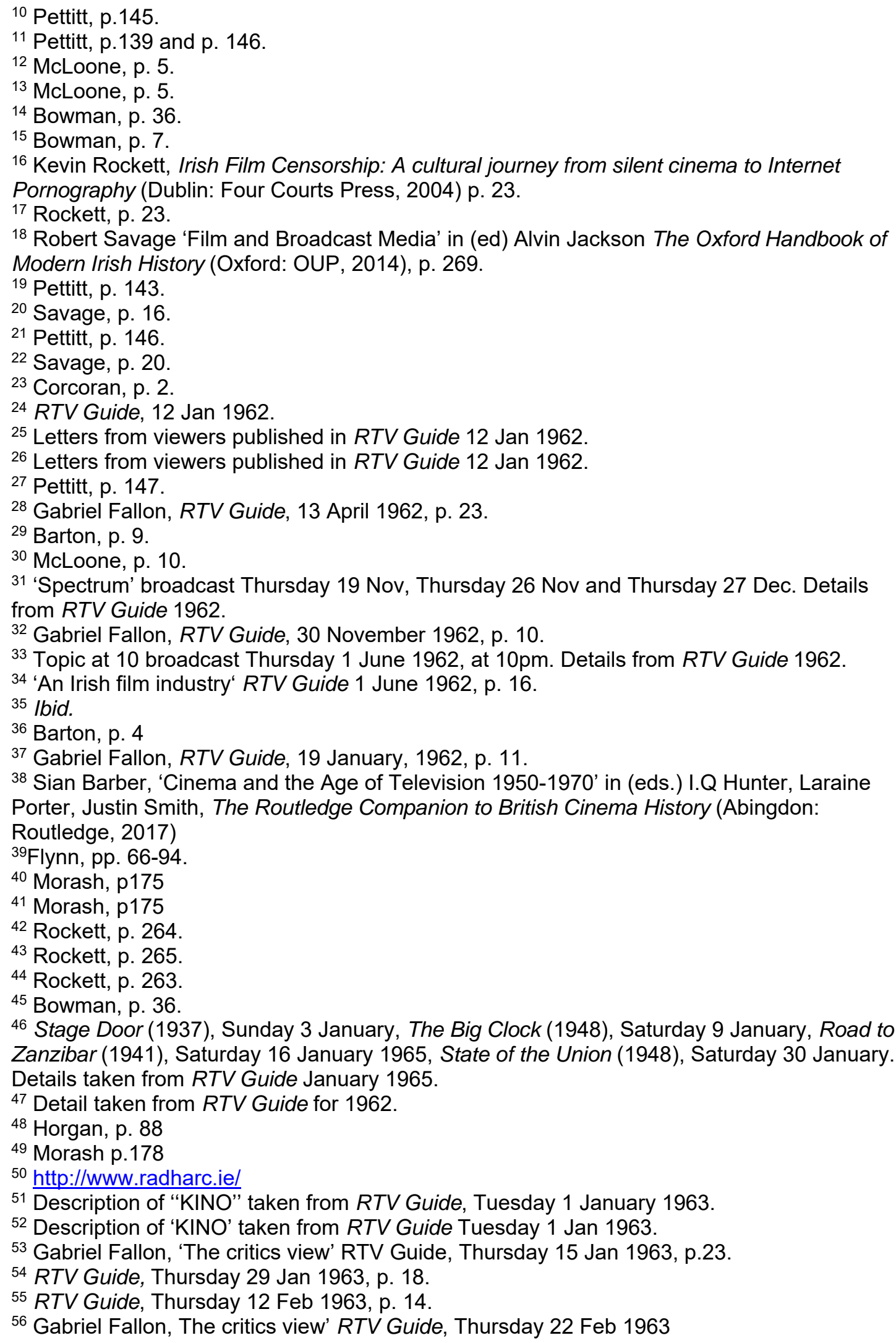




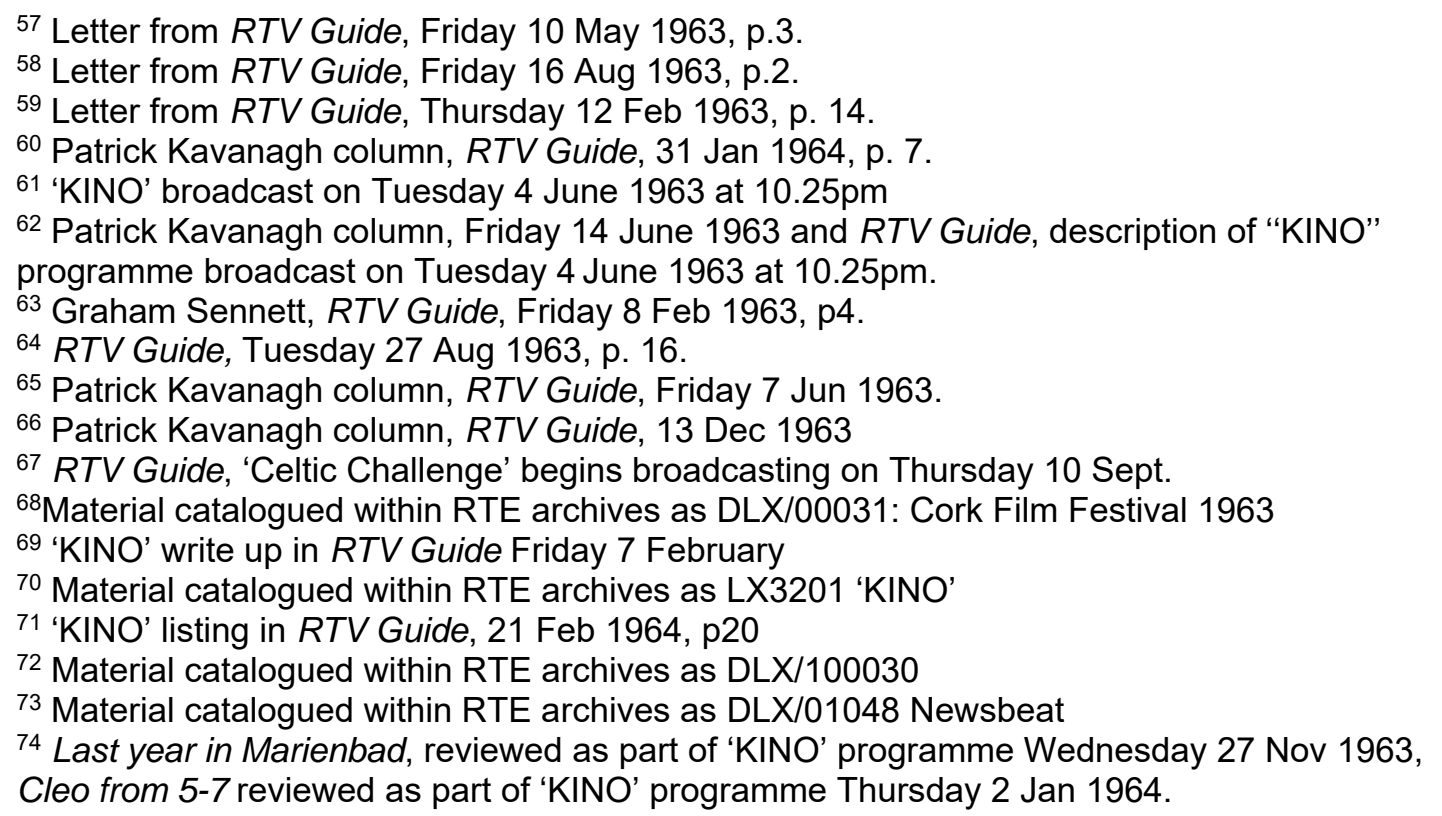

